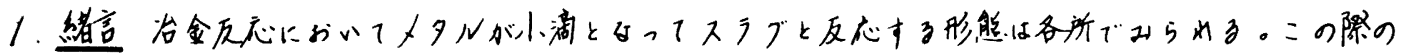

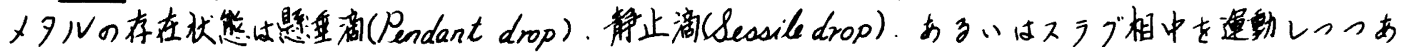

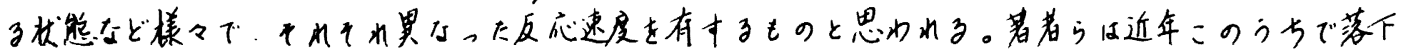

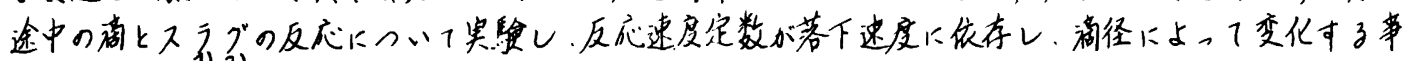

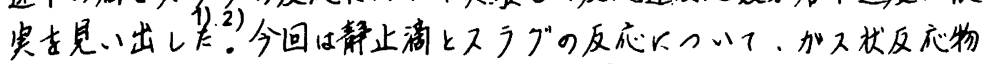

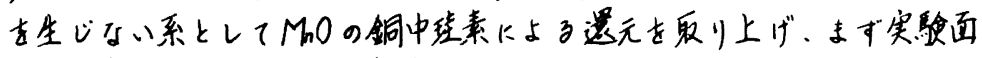
から調查レた啙果について報告扵子。

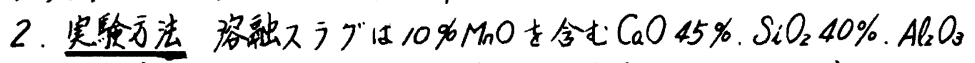
$5 \%$ の組成のものを用い、:れとCu-5\% Si合金を1500兄で反心させた。

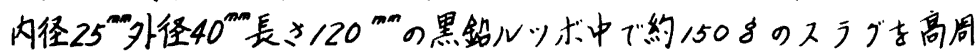
波溶解し1100 mmのスラグ局を形成上七所定の温度に保へ。メタル滴は 予め球相当径がアー12 mmになるよう科量した小塊をまず黑敛)ズル内

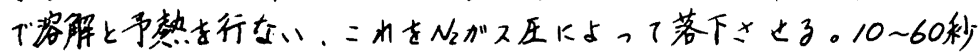
间反心させてからただちトルツボミ゙と水中に投入して急冷才る。試料は ルツボ底から取り出し、Mnと一部Siの分析を行なった。

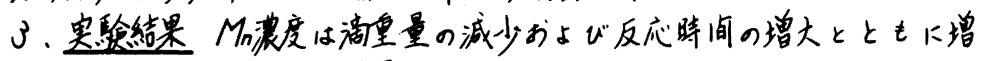
加才る。小さ、滴では試料量の制限からM分析しか行えないが、大き

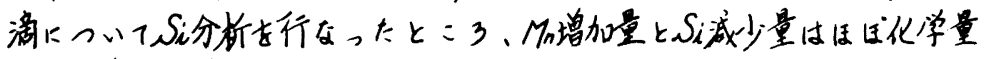

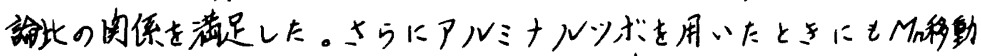

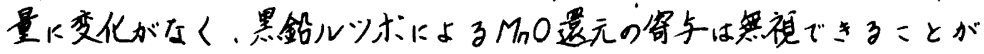

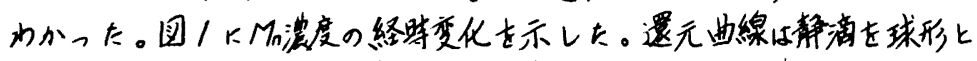

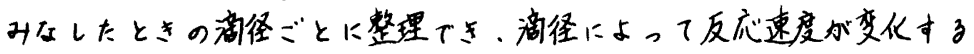

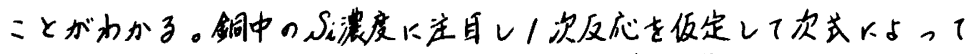
透元曲線を整理しk. $d x / d t=a k(5-x) \cdots(1) \quad \frac{1}{a} \ln \frac{5}{5-x}=k t \cdots(2)$

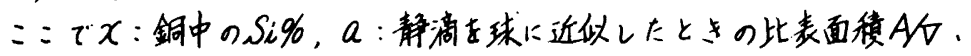

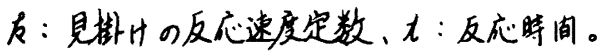

(2)式のプットを图2に示す。反心初期では静滴の球相当径ジとに一本 の直線て表现でき，/次反心で近似でミることを示している。直線が原

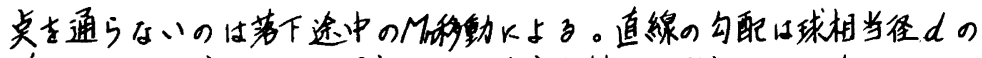

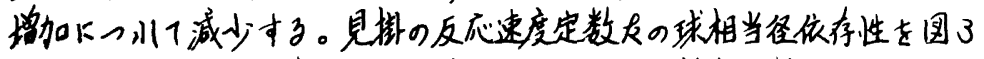

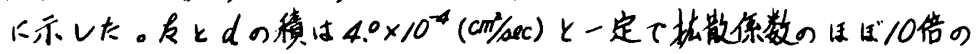

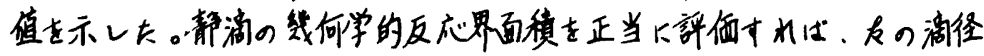

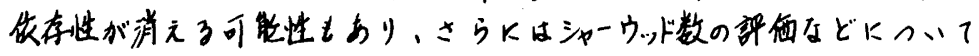
$t$ 今後追求さるべものと考えられる。
文献１）吉井、石月，伊藻。
: 鉄七舒 $58(4972) ， S 3$
2）齐藻、石井、吉井。
：铁と领园
2303

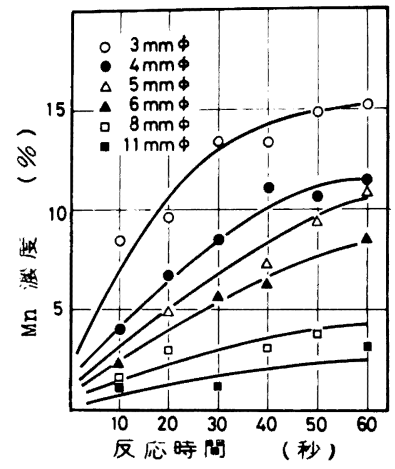

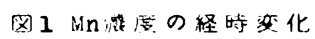

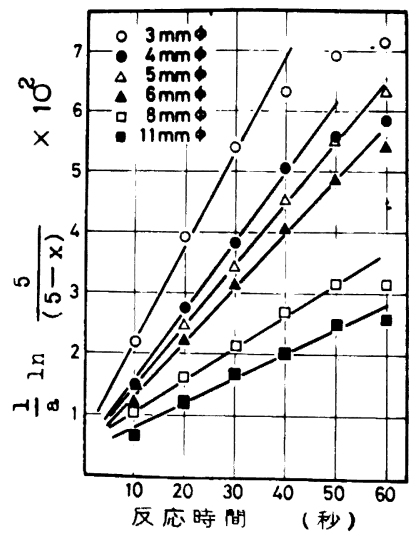

田2一次反応プット

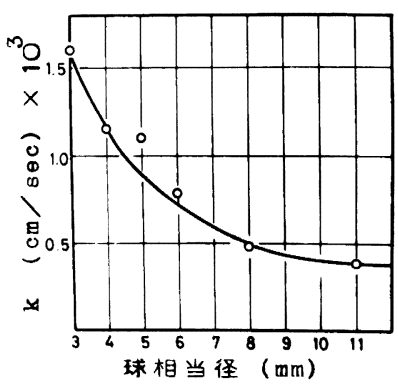

因3速度定数と滴径 


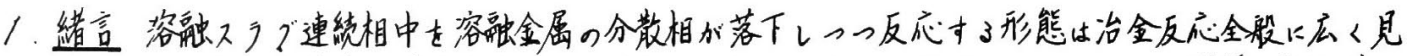

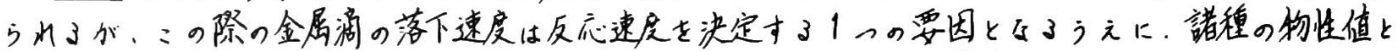

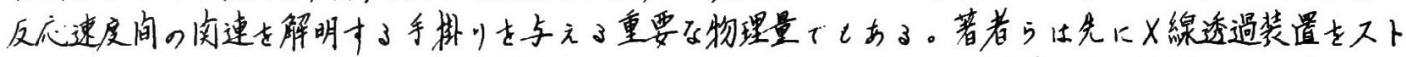

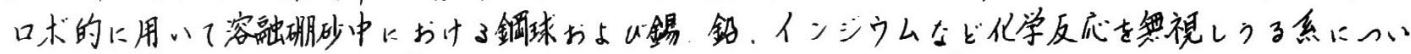
て落下速度を测定し新告した”。今回はより高温の系に对して同し装置の適用を誠みさらにスラブ中Mn の還元反心が落下速度に与える影響について检討したので教告才る。

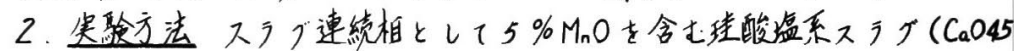

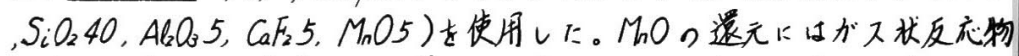

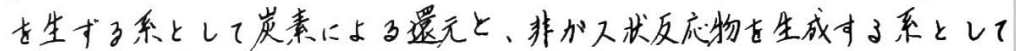

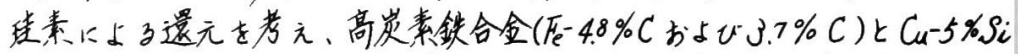

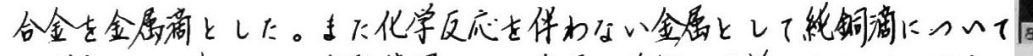

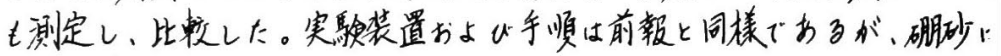
くうべ線透過能が小メ、ため、X線強度を $110 \mathrm{kV}, 300 \mathrm{mAkアップした}$

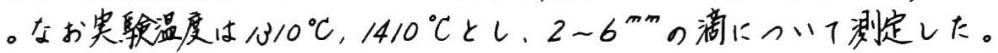

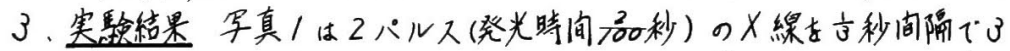

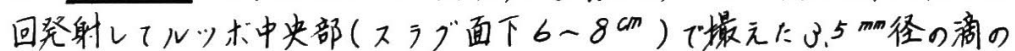
落下犾能を示才。(a)は紤銅滴の例で、Cu-5.0\% Si を示した。写真の例では球形を保持しており気沉などの附着もみうれず、

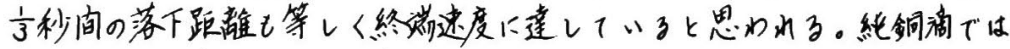

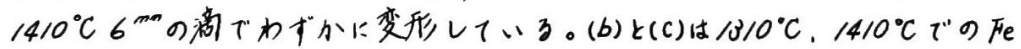

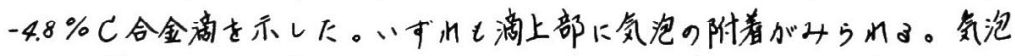

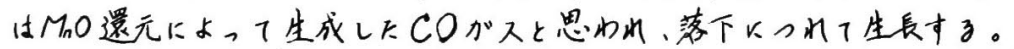
こ川による浮力の增加のため落下速度は徐々に小さくなる气泡は最初薄 譄犾て裙上半分を爱うようにみえ、次、1゙上部に集まってれ味を带び、つ

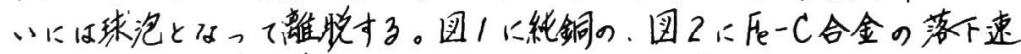
度を示レた。Cu楛の落下速度は国中に参考七した繁限媒体中での固体球の

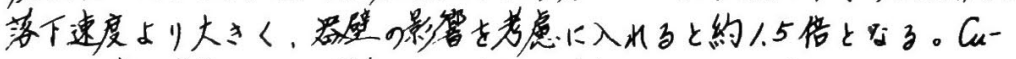

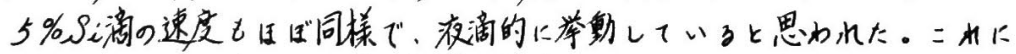

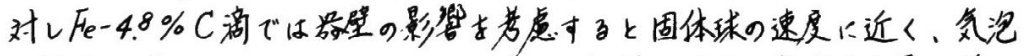
の効果が現われている。4

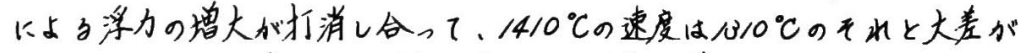

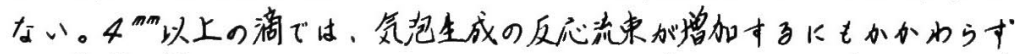

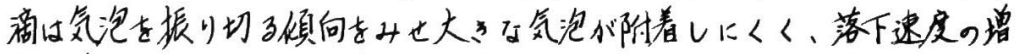

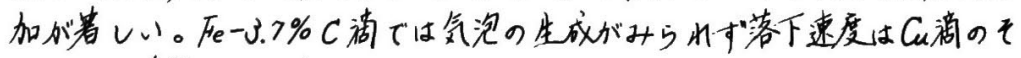
川上近、举動をしめ寸。

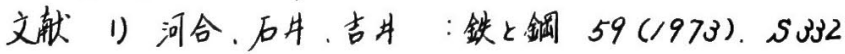

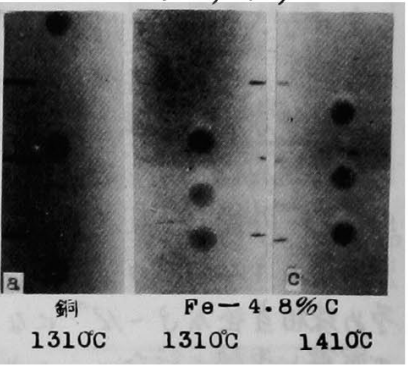

军其 1 金属滴の落下举初

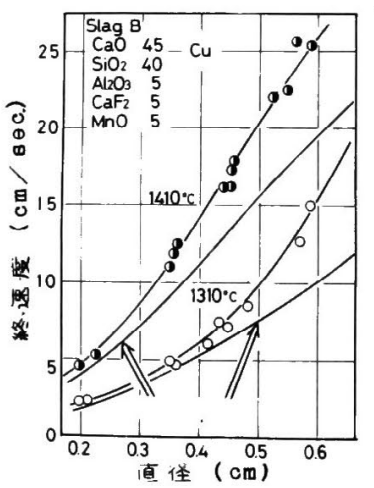

因1鉰滴の落下速度

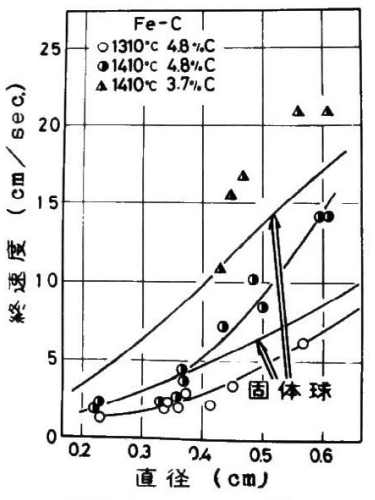

因2 $\mathrm{Fe}-\mathrm{C}$ の落下速度 
$669.162 .275 .2: 669.162 .263 .45: 669.046 .582$

669.775: 669.782

$74-\mathrm{S} 363$

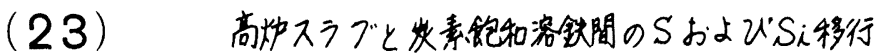

名古屋大学工学部 作々健介

井上道雄

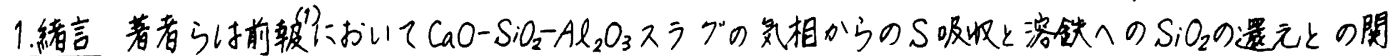

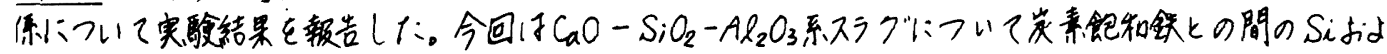
认゙S移行速度の閣係を明らかにしよと試みイ。

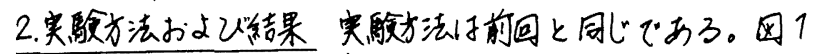

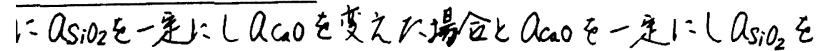
变えイ場合の各々につレてシクカの退元速度(a，b)及びスうブ

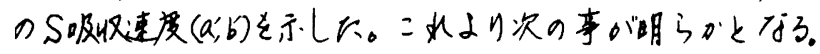

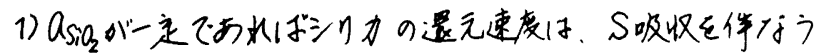

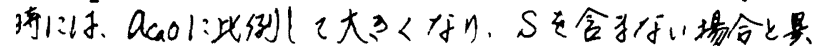

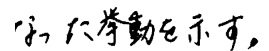

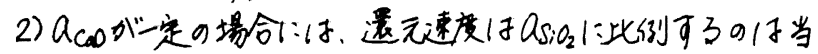
然であるが、S吸収を伴仿う場合の方が速い。

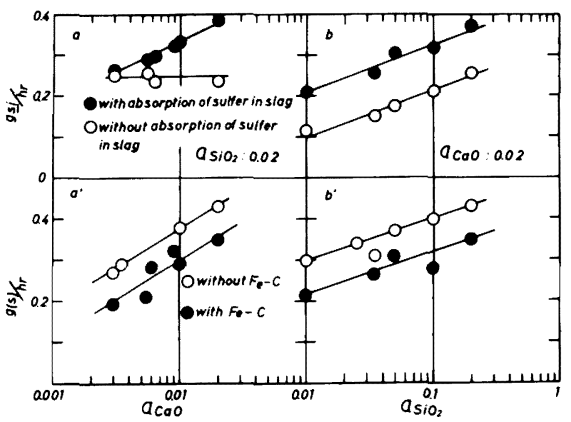

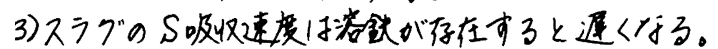

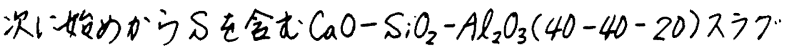

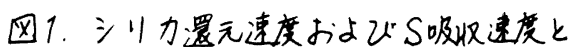

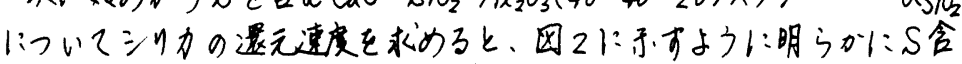

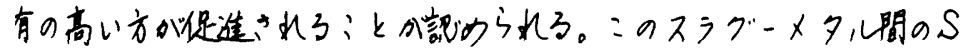
の移行について测定(て結果、硫黄ははじの溶铁内に移行し再びスうグ

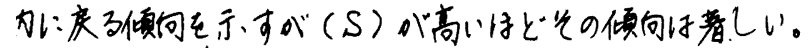

3.考察既软の゙・゙く

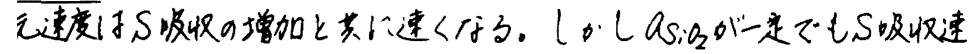

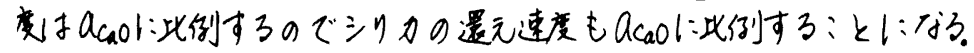

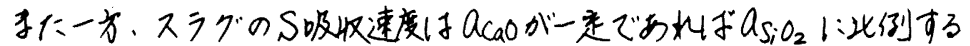

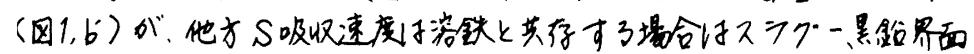

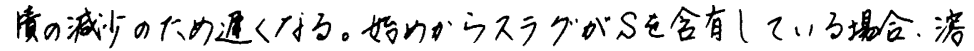

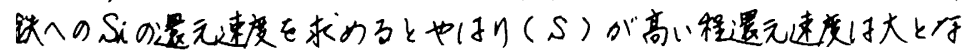

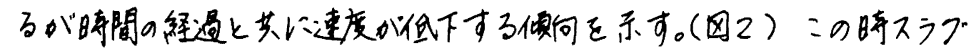
一メ夕ル界面を通してのS移行をみると四に示すように一一旦得硫し、再

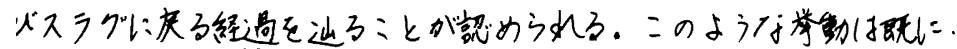

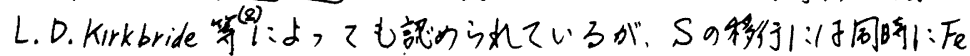

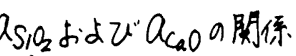

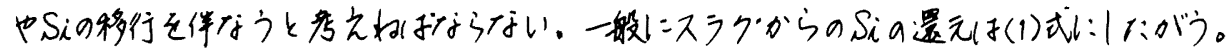

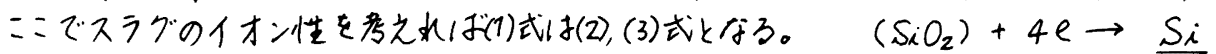
$\left(S_{i}{ }^{4+}\right)+4 e \rightarrow \underline{S_{i}}$
$2 \mathrm{C}+2\left(\mathrm{O}^{2}\right) \rightarrow 2 \mathrm{CO}+4 e$

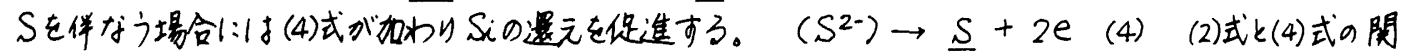

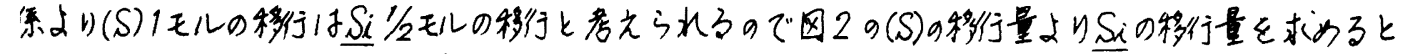

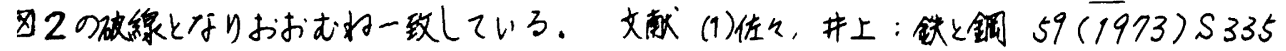
2) L.D. Kirkbride, G. Derge: Trane. Met. Soc. AIME 218(1960) P.87 
（24）岑素飽和鉄による硫黄を含んだスラグかるのら゙の遈元について

\section{九州工業大学。芦侬正博 三菱金属鉱業重松敏明}

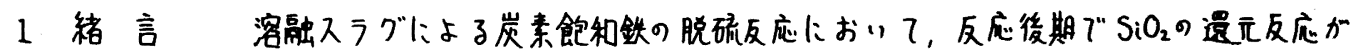

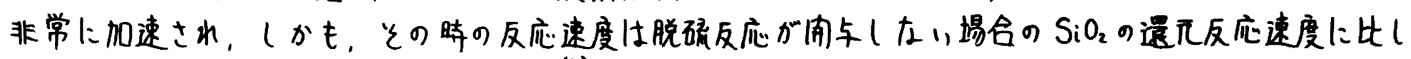

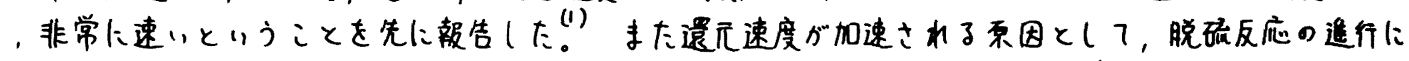

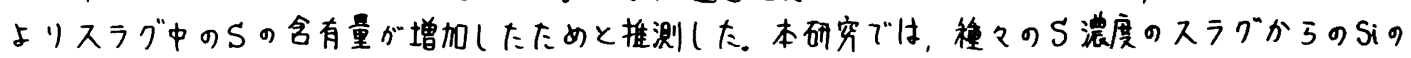
薑元速度を测定し，還元速度とスラグ中のら漊度の阅保を求のた。

2 方法装置及心゙方法は，前報と同じである。るつほは黑铝製で，上部るつぼと下部るっ ぼの2段になつている。スラグを上部るつぼ、メタルを下部るつぼに入ル，高周波炉で所定の温度まで 上㫒させたのち、スラグを下部るっほト落下さ世，反底を用 始させる。

3 結 果 $55 \mathrm{CaO}, 45 \mathrm{SiO}_{2}$ 系スラグに S $0.1 \%$

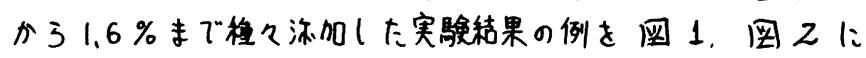

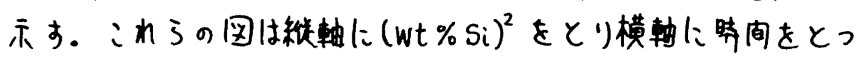
たものブある。为图の埸合近似的に次式が成立(た。

$$
\left(w t \% \underline{S_{i}}\right)^{2}=K\left(t-t_{0}\right)
$$

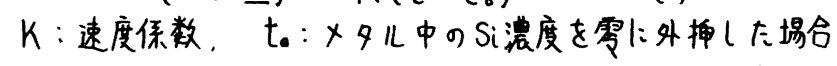

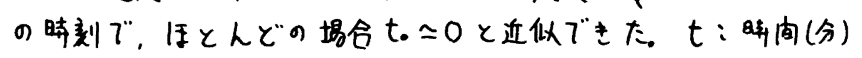

(1)式の阑保は、スラグ中のS惯度が $0.4 \sim 1.6$ ，温度が $1500^{\circ}$

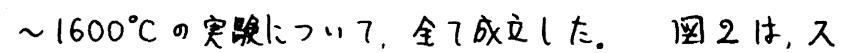
ラグ中の 5 涨度を0.1\%と娍少させた場合の結果で，(1)式を满

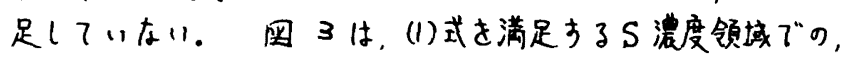
速度保数KとS淟度の用保を末したものであ子。

4. 結言 $\times$ タル中のSi浓度と反応㫢间の周保は， スラグ中のS淟度が 0.2 〜 $0.3 \%$ 以上の堨台，(1)式を 满足したが，とれ以下では Sを含まない堨合に成立す 子直楾肉保 ${ }^{(2)}$

$$
(w t \% \underline{\underline{s}})=k^{\prime}\left(t-t_{0}\right)
$$
に近ブく倾向を示した。

\section{文献}

(1) 鉄と銅 59 (1973) No $11, \$ 334$

(2) 鉄と钿 54 (1968) P 1437

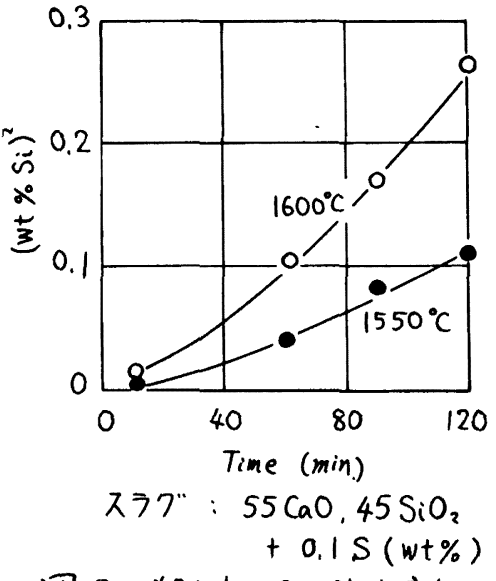

四 2 X片中のSiの㫢问変化

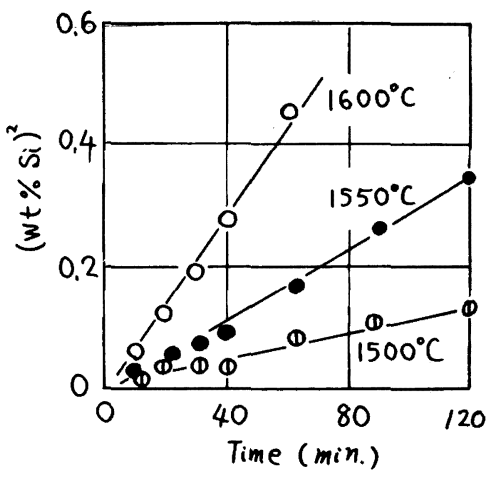

スラク": $55 \mathrm{CaO}, 45 \mathrm{SiO}_{2}$ $+1.6 \mathrm{~S}(w+\%)$

同1X外中のSiの時间変化

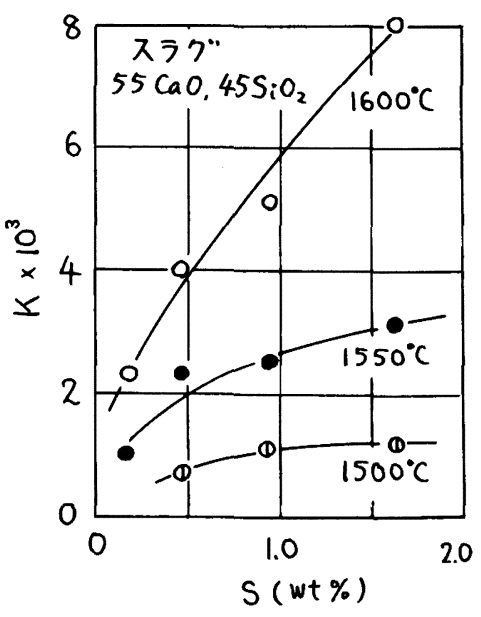

四3スラグ中のS蕞度と速度 保数的阐保 
烧秸原料の造粒性について

住友金属中央技術研究所理博吉永真马

$$
\text { O工博一伊達棯 }
$$

烧結原料の造粒性は，烧結時におけ檤切な通気度の確保を保障し，烧結鉱の強度と生産率の向上下

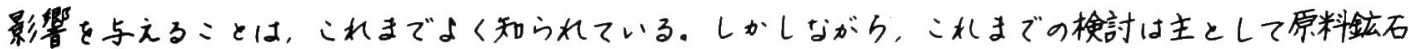
の物理的性状について行引れれ，鉣石粒子表面の物理化学的性筫についてはあまク検討されていない。

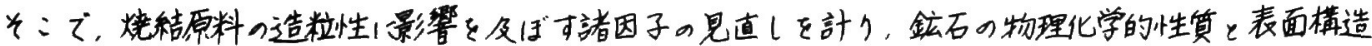

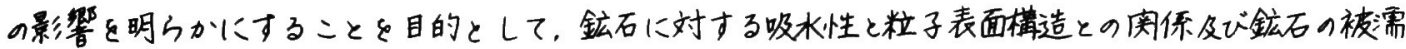
性さらびに見掛け密度の增加と通気性との用係を検討したので辄告する。

1.鉱石に対する吸水性と鉱石の表面構造との闺係

图1は，座地の異なる鉄鉱石の浸透法”による吸水特性を示す。 困に浔められるように, 水の上异温度は二ューマンらがーののグル 一プを形成し，ゴア系の鉱石が米2のグループを形成する。まに Magnetite系鉙石およびSpecalarit系鉣石は上异速度が著しく低い。

きた。これらのブループの鉱石粒子の表面の走查形俺影写真を示す。 写真にみとめられるようにHematite鉱石において，䊅晶の速状况

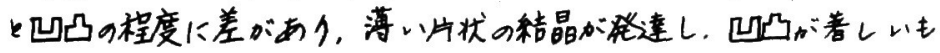
のほど吸棑が著しい。

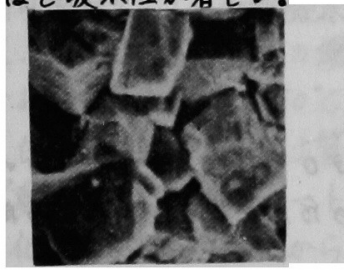

$M$ M. ニューマン

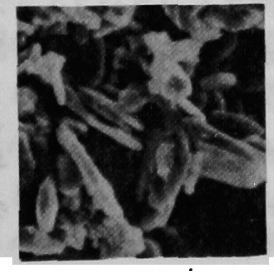

フォーメント

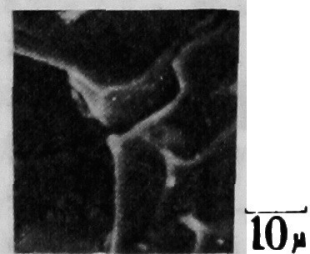

キャロル・レーク

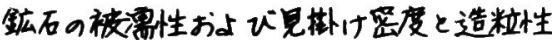

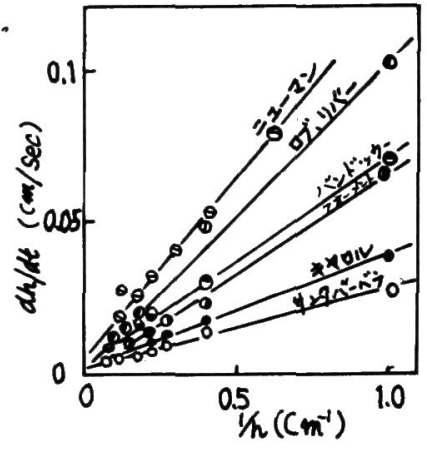

图1各㮔銘唡锌石の吸水 特性

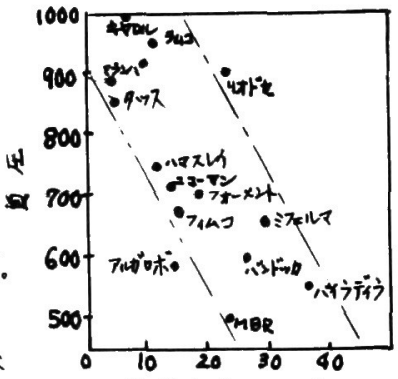

是期密度首加比(R)

因2見脚け宾度增加比 と夏圧と送俰

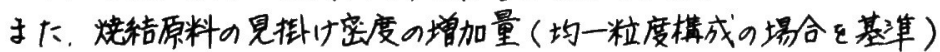
と水分4\%添加時における負圧との成係は 园2に示す。四にみられるd うに，見掛け密度の增加の大きな場合ほど，通気量が增大する二とを示す。

表 1

1)日本化学会实駼化学請座界面化学(九善)

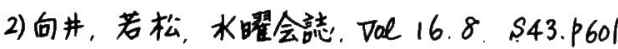

3) E. Moganek. Stall u. Eisen Nr20 1972. P1002

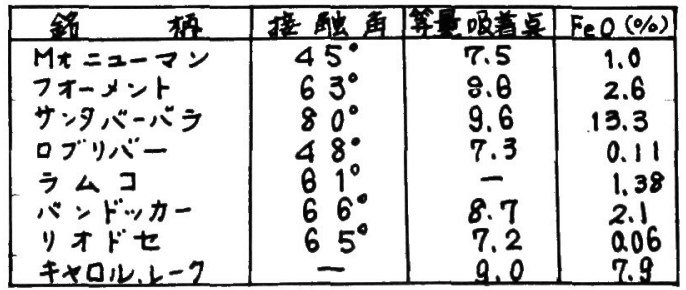


$74-\mathrm{S} 366$

621.785: 621.928.7:621.3.017.71

（26）㜔结主排気用電気集娥

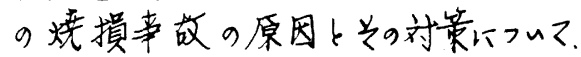

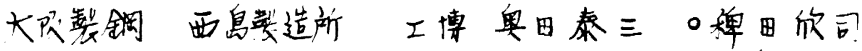

枈田隆藏中身俊記

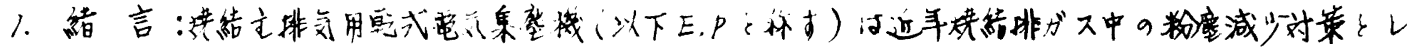

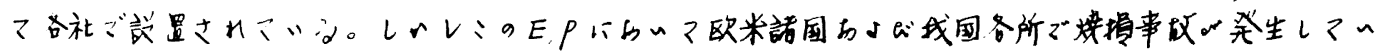

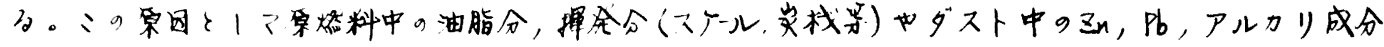

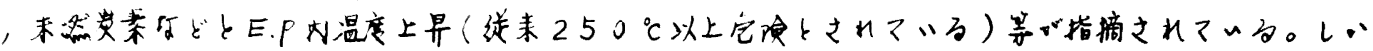

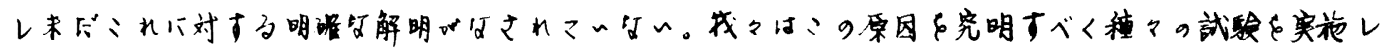

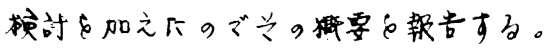

\section{2 試駼方法}

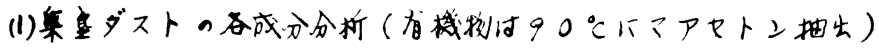

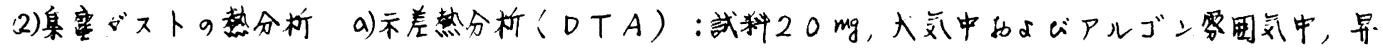

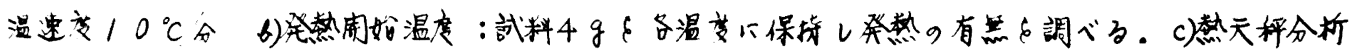

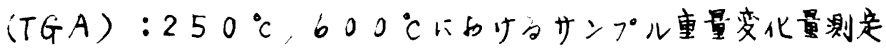

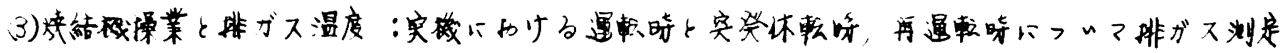

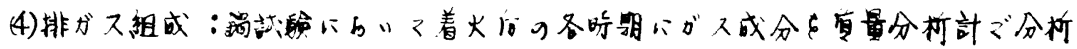

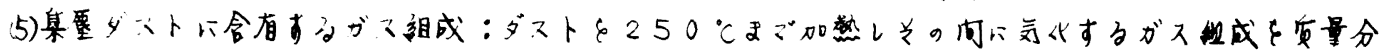
折計之分析

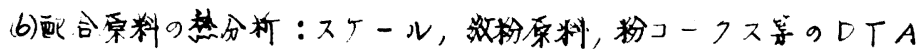

\section{3 結果的小心考察}

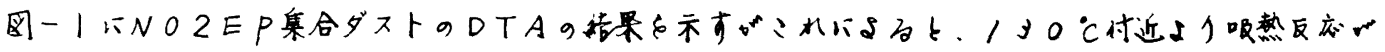

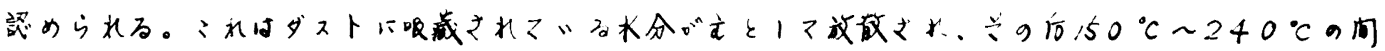

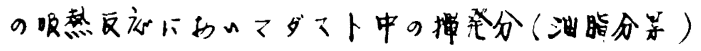
9等(

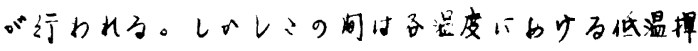

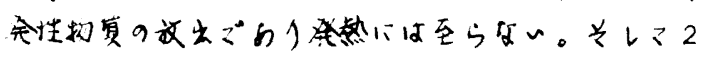

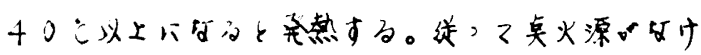

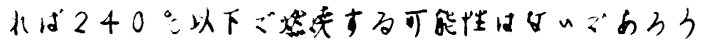

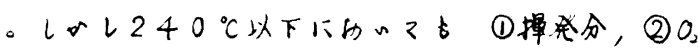

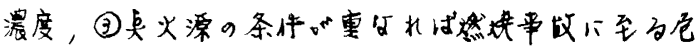

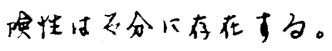

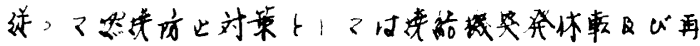

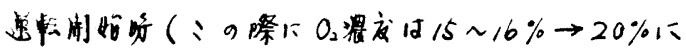

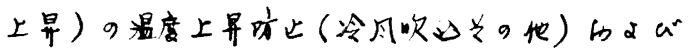

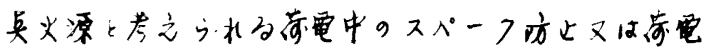
原上片里取る:に必必要でんる。

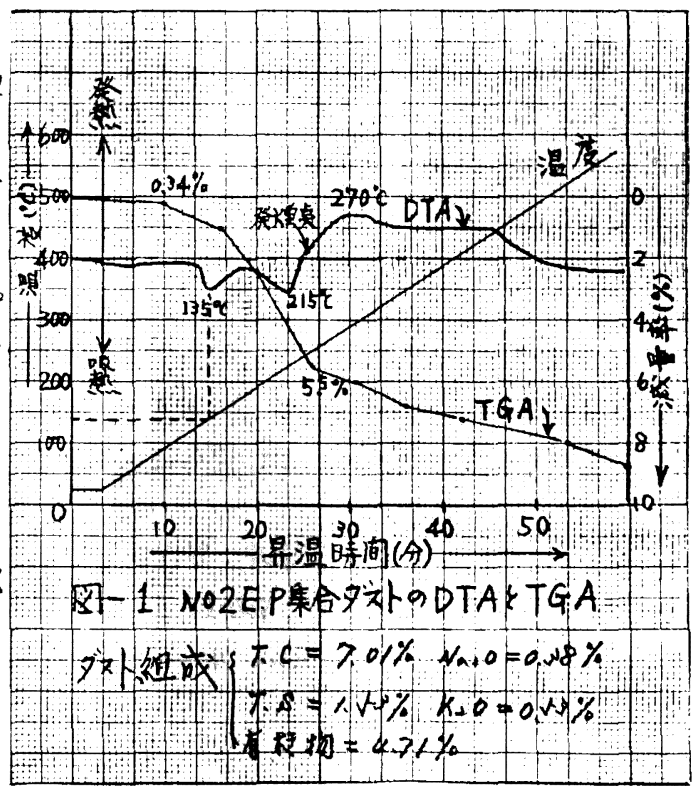


I. 緒言 烧結时の造潭の遇程を知るために行与ったつークス灰

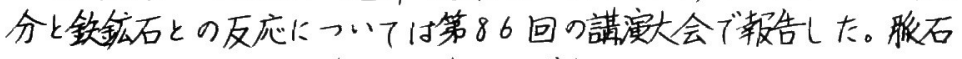

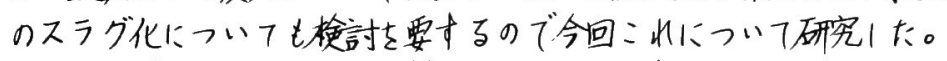

II. 定姶方法 前報と同样卜鉃釷后に完を穿门 スラグとするべ き服石を入れ, $\mathrm{CO}-\mathrm{CO}_{2}\left(\mathrm{CO} / \mathrm{CO}^{2} \mathrm{CO}_{2}=20 \%\right)$ कるいはAr雾囲気

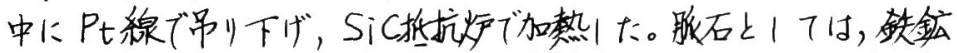
床の粘土 $\left(\mathrm{Al}_{2} \mathrm{O}_{3} \cdot 2 \mathrm{SiO}_{2} \cdot 2 \mathrm{H}_{2} \mathrm{O}\right)$ と茂山鉃鉱石の脈石を用いた。茂山鉄

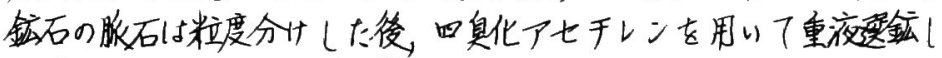
て得にしので，殄んど硅石筫でちった。弓のなかで150メ・シュ以 下の粒を使用し，スラグ成分とし7は: 北と20\%のの酸化铁の粉文を

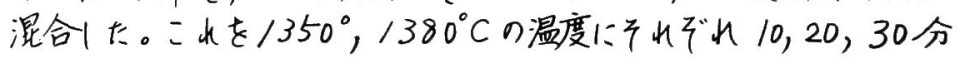
間保持|た。粘土の堨合、スラグ成分々(ては服石のみ，あるいは脆 工博 吉井周雄 石に 10〜20\%の酸化铁粉をよく混合けたものを用い, 前記の雾团

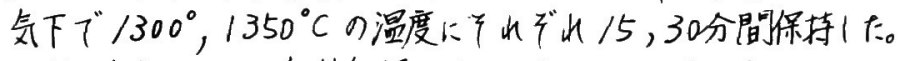

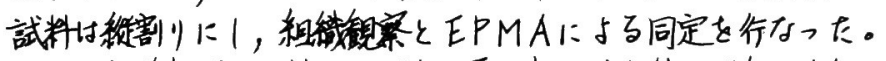

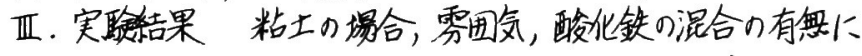
かかわらすスラグは $1350^{\circ} \mathrm{C}$ の温度で溶门7，铁鉱石壁と良く接 触1た。一例と17，粘土筫の鉙物の子を詰以込人だ試料の租 瀻写真とEPMAのチャートを四.1に示寸。目.1からスラグ化 (七.化合物中、鉄鉱石壁からの酸化铁の供給の㭧いと二ろは末 溶解であるが, 壁と接触けているところは客解けたスラグが出 来，Fe含有量は内部程低くなっていることが分かる。(か，产 粘土下酸化铁を混入17图.1の埸合上同ば条件で加热するとス ラグ全体が容けた。

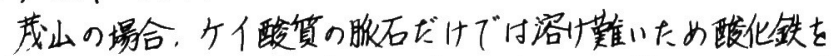

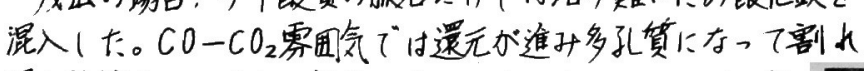

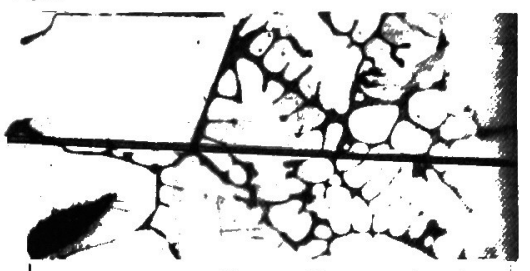

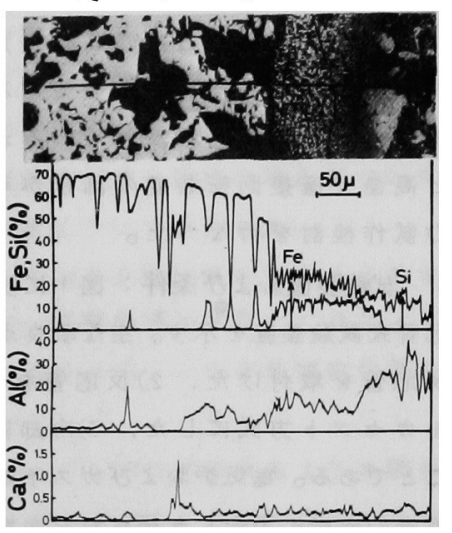

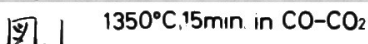

易く铁鉱石はルツホの役目をなさなくなり，且つ，酸化铁

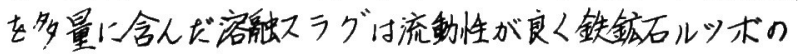
外面近人ま7゙流山，酸化铁を析出(つフ㠜固17いる:

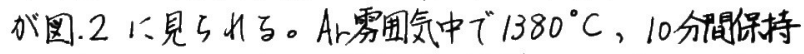

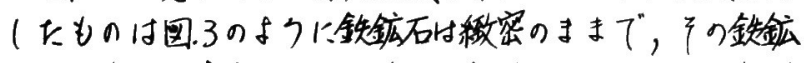
石ルツボ中に存在1ていた脈石は溶融いていたが，比較的 大さい粒り硅石はなお周边がスラグで团手れたまま存在 フいた。前報のコークス灰分の場合と此較(7脈石の方が

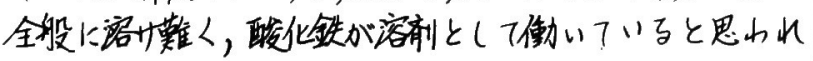
布。

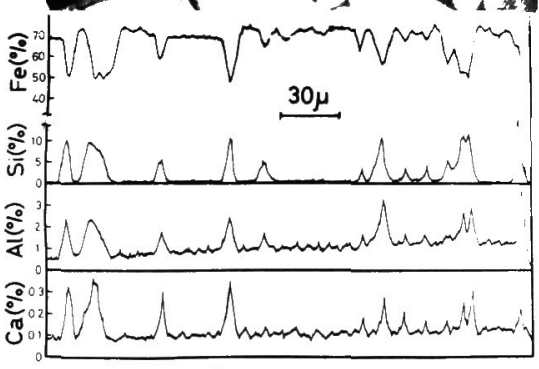

国. $1380^{\circ} \mathrm{C}, 30 \mathrm{~min}$. in $\mathrm{CO}-\mathrm{CO}_{2}$

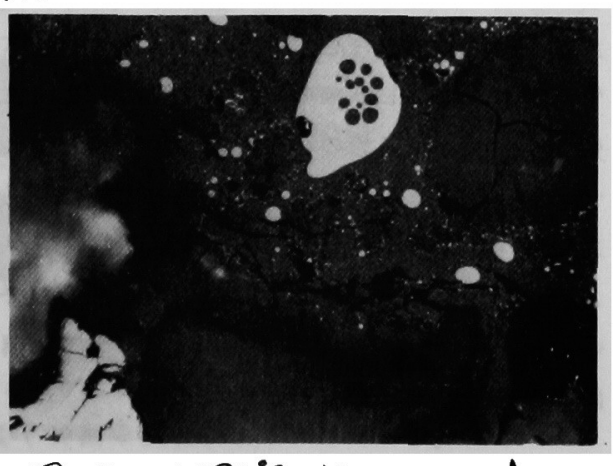

因.3 $1380^{\circ} \mathrm{C}, 10 \mathrm{~min}$. in $\mathrm{Ar}$ 


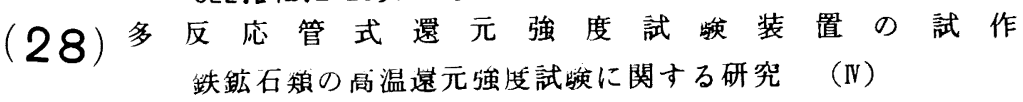

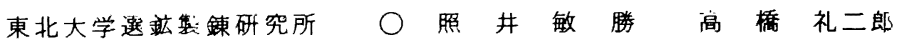

$$
\begin{aligned}
& \text { 八木順一郎大森康男 }
\end{aligned}
$$

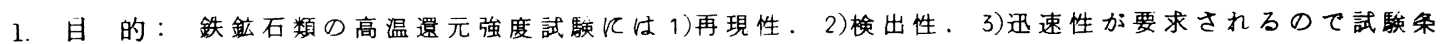

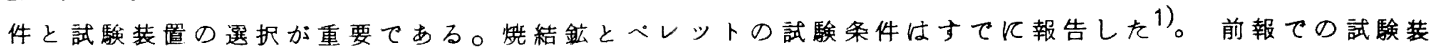

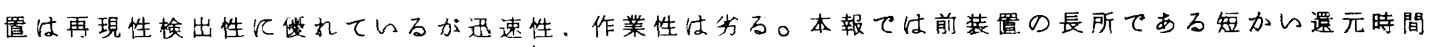
と高温て直接回転強度の㴬定が可能てあるとい52点にさらに試験の迅速化を計るため新しい試験装置 の試作検討を行なつた。

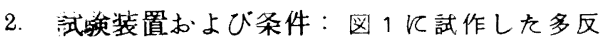
応管式試験装を示す。主な改良点は1）４本の 反応管を取付けた。2)反応管を二重にし内筒 をカセット方式にした，3冷却器を取付けた ことてある。䉓気师およびガス予熱用反応管を 所定の温度飞設定した後試料を充填した内筒を 反応管飞入れる方式をとり，試料の界温時間を 短縮した。カセット方式と佮却器の使井により 遥元終了後の给却時間を短編した。4 本の反応 管を取付け，カス统通采を4分割方式にしたの て同時に4 試料について試験がてをた。試料と して塩基度 1.440工業用焟結鉱を使用し, 試 騃条件的前報1）と问様て，望元と強度測定の分 雖および造元カスの酸素ポテンシャル制御 ( $\mathrm{CO}-\mathrm{CO}_{2}$ 混合ガス) を行なつた。

3. 結果：前報の装との性能比較するた め1)迅速性，2）娭出性，3)再現性について柍討 した。表1亿改良前伐の試騃所要時間を示した。 作業能率は6〜8倍上つている。図2 亿低温 ( $550^{\circ} \mathrm{C}$ (1)) と中温 $\left(750^{\circ} \mathrm{C}(2)\right.$ における4 本の反応 管加ら得られた造元强度試験結果を示した。 反応管間の機差はとんとなく，をた同一反応 管によるくり反し試騃の結果す满足できる再現 性を示した。反応管の惩が異なる以外は（130

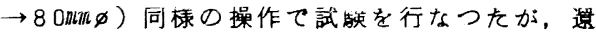
元強度は邀元采件に支配され単一反応管の場合 と同棣娭出性す充分である。その他，高温まで の年温造元試娩 (950 Cまて35〜40分で急速 に舟温させる方法) b可能になつた。

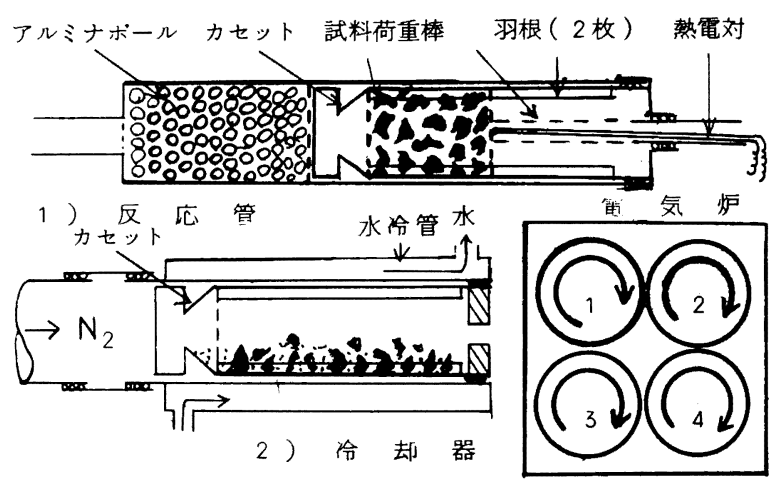

図 1 多反応管式強度試験噮

3）反応管配置図

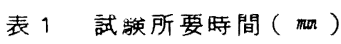

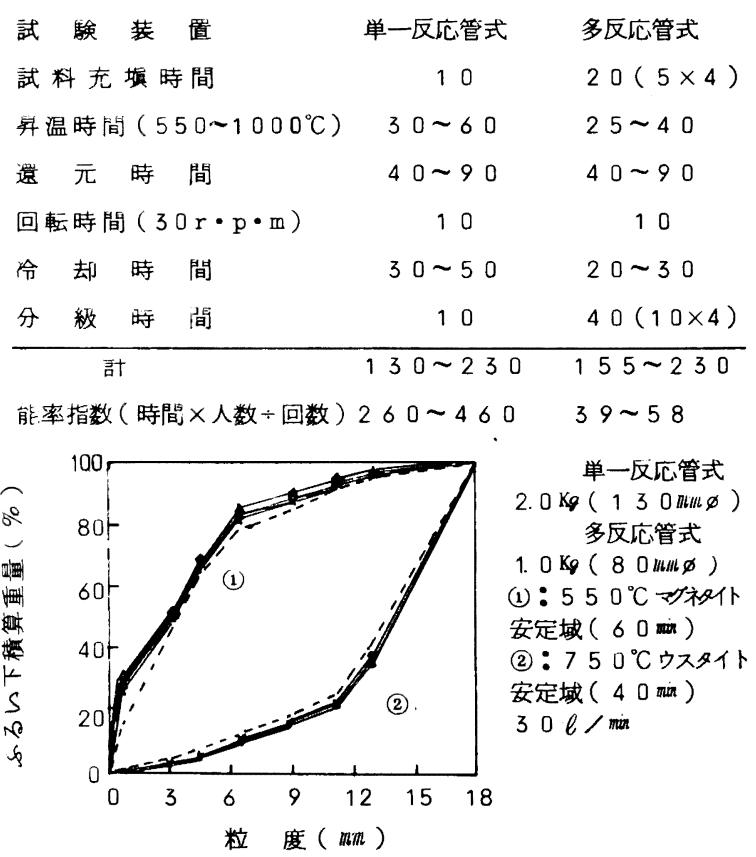

図 2 同一試騃采件《おける算の比較

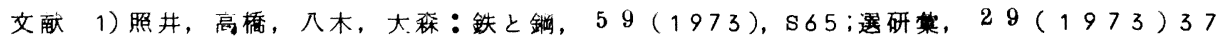




\section{（29）ペレットの還元割れについて}

新日本製鉄基礎研究所近藤真一, ○佐々木稔,

伊藤董

1. いきさつ：高炬内でペレットが紐化する可能性につんては，管状サンブラーで操業中の高炬 から採取した試料中で破損したぺレットが見いだされたととから，城本らが予測しているとてるである。 厇畑1高炬の解体調查の結果, 塊状带の一部領域で, ペレットが粉化するにはんたらないまです, 表面 に亀裂の入っているてとが観察されている。 触れられている。本研究では各種ペレットにおける亀裂発生の条件と機構について検討した。

2 実験結果と考察：10 数銘柄のペレットの中からそれそれ平均見かけ密度を有するすのを 選びだして実験試料とじ, 温度, ガス組成, 時間を変えて還元したあと, 車裂の発生状況とパラフィン 処理した試料につんてのふくれ率を調へた。龟裂を内部法孔と見なした場合のペレットの体積変化率を, ここでは見かけのふくれ率として扱った。

温度と見かけのふくれ率のあいだには，図1に示すよ5に，3種のペレットで代表されるような関倸 が見いだされた。ペレットA，B酸性ペレットてともにへマタイト結合でるが，見かけのふくれ率 の変化傾向が異なる。還元率は各温度で后々んど同じなので，゚レットの構造が関係しているのではな らかと思われる。酸性ペレットだけでなく自溶性ベレットすA型お上びB型に分類された。ペレットC

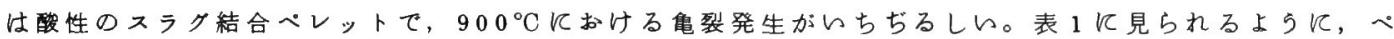
レットAでは亀裂の発生は hematiteから magnetiteへの還元段階に対応してんる。ペレットCではカ ス組成を $\mathrm{CO} 30 ， \mathrm{~N}_{2} 70$ としても同程度のふくれ率を示すので, マトリックスのスラクが鲁裂を伝播 しやすくなる条件下で, ベレットの表面層で magnetite化が進むと, 多数の亀裂が発生するだけでなく 中心部まで伝播すると考えられる。

以上の結果から、ペレットの還元割れはペレットの種類でれぞれ起てりやすい温度, ガス組成条件 があり，さらに亀裂発生の程度によっては炬内で崩壊する可能性すあるととがわかった。

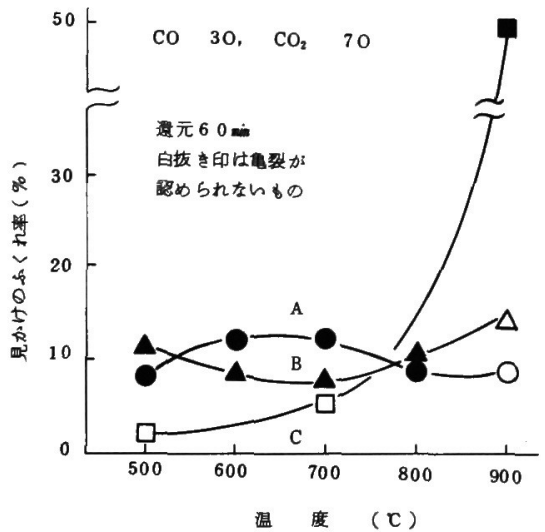

図1. ふくれ率と還元温度の関係
表 1. ベレット表面での亀裂発生状況:

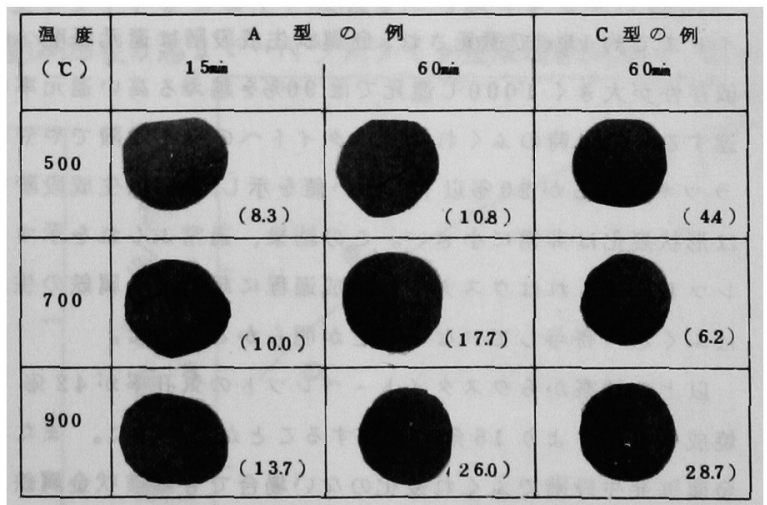

（括根内比曾元事\%）

1) 城本, 金山, 奥野、磯山：鉄之鋼， b/(1971)，P.1606

2 ) 有野, 他: 本 88 回大会で発表予定, 3) 学振 54 委（神鋼中研提出資料）：No.1297

4) 近藤, 佐々木, 伊滕, 草鹿, 南田：鉄と錀, 60(1974), S 12 
1. 緒 言 ；ウスタイトに還元されたペレットは高炉内の滞留時間が長く炉況に大きく影響すると推定さ れるため、ウスタイトの特性を調べるととは重要である。そとで、ウスタイトまで、およびウスタイトから金 属鉄生成の 2 段階還元を行ない、還元率変化、ふくれ変化およびウスタイト段階の物理性状を走查型電子顕微

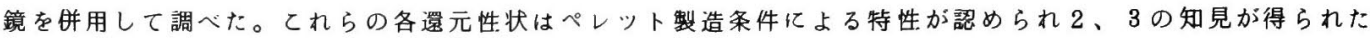
ので報告する。

2. 実験方法；高純度へマタイト鉱石に石灭石、石英を混合し、眽石量 8 w t \% 一定でかつ塩基度を調整し た生ペレットを代表的結合組織が得られるように適当な温度で焼成した。これらの焼成ペレットを前報と同一 装置により $\mathrm{CO} / \mathrm{CO}_{2}=60 / 40 、 900$ C でウスタイトまで還元し、その後 $\mathrm{N}_{2}$ 中で所定温度に調整して還元ガスを $\mathrm{CO} / \mathrm{N}_{2}=30 / 70$ に切り換え $800 \sim 1000$ C で還元を行なつた。との間ふくれはカメ三㵊影により還元率と同

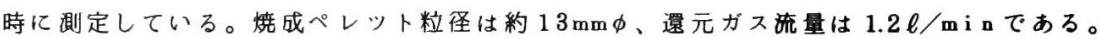

3. 実験結果; ペレット製造条件を変化させ 5 種類の代表的 結合組織を有するペレットについて調べているが、とてではカ ルシウム・フェライトを多く発生する（焼成温度 1200 C、塩 基度 1.5 ) のペレットを1例として述べる。

ウスタイト粒子はその断面写真（写真 1 ）加らへマタイト粒 子形状を残し、中心部は空洞化しているととがわかるが、電顕 により立体的に観察すると角柱状又は板状で平行に粒子内深く 切り込まれた空隚が翟められる。金属鉄は断面写真上り多孔質 化したウスタイト粒子表面に生成しており、粒子間には金属鉄 小粒子も存在している。電䫓観察では局部的に写真のような紼 維状金属鉄が多数認められる。

同蝩ペレットの還元率、ふくれ変化を図1亿示す。ウスタ イトまで約 $1 \mathrm{~h} \mathrm{r}$ で還元され、金属鉄生成段階は還元温度への 依存性が大きく $1000{ }^{\circ} \mathrm{C}$ 還元では $90 \%$ を越える高い還元率に 達する。この時のふくれはウスタイトへの還元段階でややバ ラッキがあるが $20 \%$ 以下の低い值を示し、金檒鉄生成段階で は形状変化は非常に小さい。この結果、通常ふくれを示すぺ レットのふくれはウスタイト生成過程に起り、金属鉄の生成 はふくれに寄与していないてとが明らかとなつた。

以上の観察からウスタイト・ペレットの気孔率が $42 \%$ と 焼成ペレットより $16 \%$ も增加するととがわかつた。また、 金属鉄発生段階でふくれ変化のない場合でも絨維状金属鉄か 認められることがわかつた。

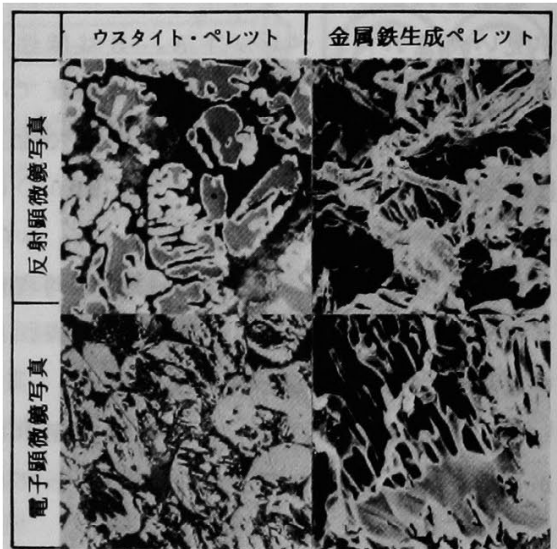

写真 1 ウスタイトペレットおよび金属鉄発生 ペレットの顕微鏡写真（還元温度 900 C

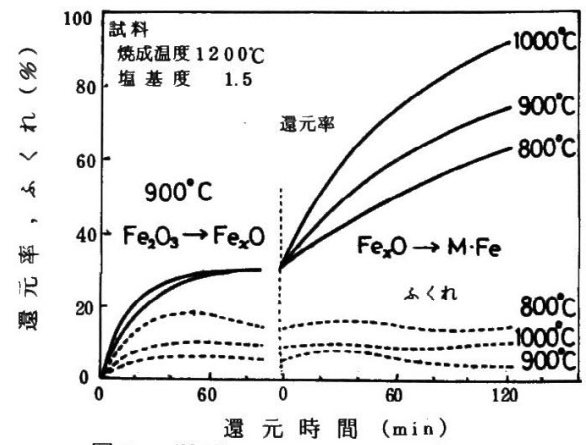

図1還元率およびふくれ変化

るお、焼成ペレットの結合組織がウスタイト・ペレット、および金属鉄生成状洗におよはす影響についても 同様の検討を行なっている。
4. 文献
(1) 西田，土屋，杉山
鉄と鋼
$58(1972)$ s 339 
622.346.1-188: 622.361.16: 532.613 .2
(31) ペレタイジング用ベントナイトの特性Kフいて

(クロム鉉历のペレタイジングト関する研究I)

昭和電工全属開登空吉村 亮一

金属辟究所茫司孝志町田好厷

1、緒言

ペレタイジングにはバインダーとしマー般にベントナイトが便用されているが、ベントナイトのバイ

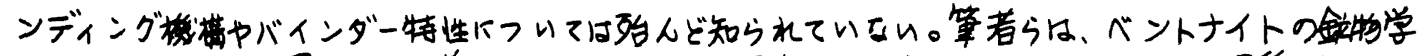

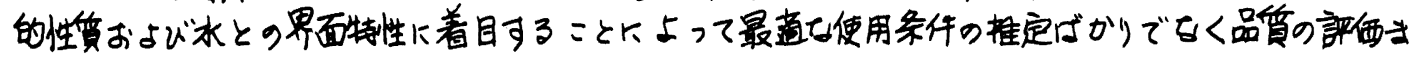

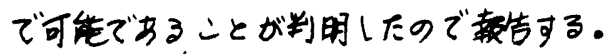

2、实娩方法

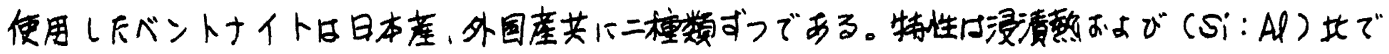

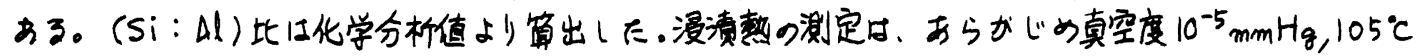

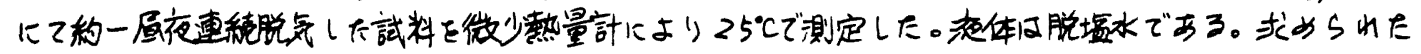

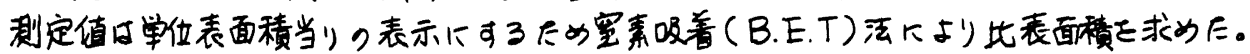

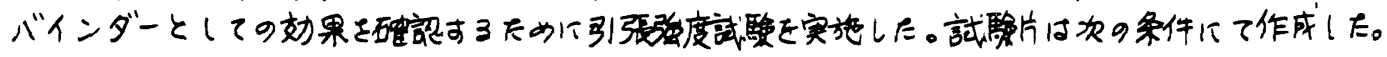

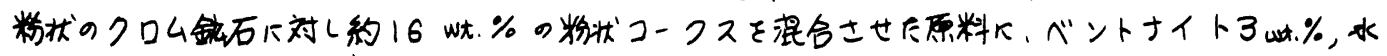

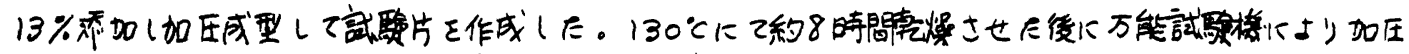
速度一定下して強度民制定した。尚、引張强度の算出には次式巨用いた。

$P:$ 測定值， $d:$ 試群片の直径 $(\mathrm{cm})$

引張强度 $\sigma_{\mathrm{t}}\left(\mathrm{kg} / \mathrm{cm}^{2}\right)=2 \mathrm{P} / \mathrm{d} \cdot \mathrm{l} \cdot \pi \quad l:$ : 試駰片9長士 $(\mathrm{cm})$

3、結果と考究。

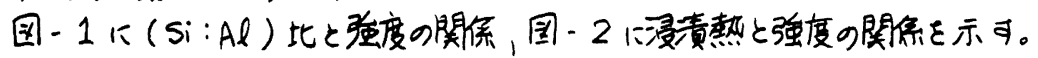

1) ベントナイトの主要鉿物はMontmorilloniteでち3。理想的 Q Montmorillonite g(Si:Al) 比 『5/2である.とのたのベントナイトの（Si：Al）比が5/2に近い程強度がかる.

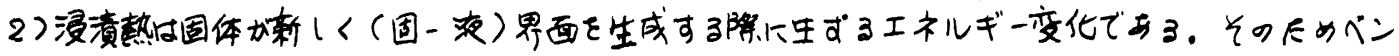

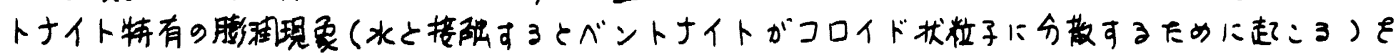

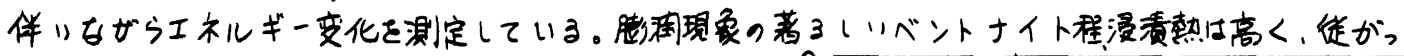

て浸责熱が高い程强度がある。

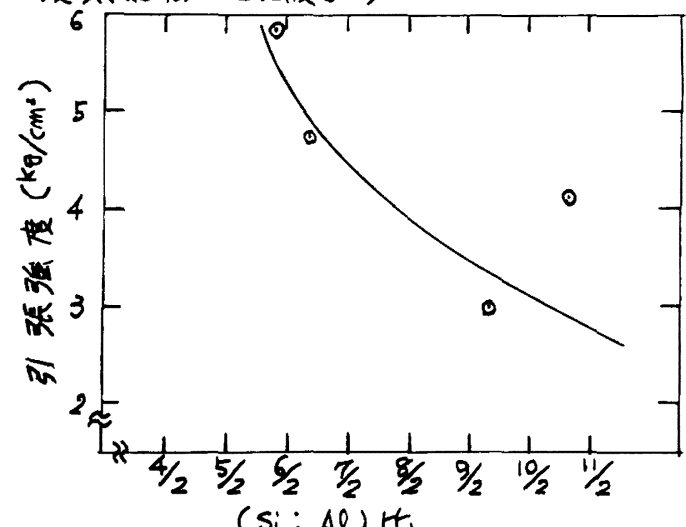

国-1 (Si:Al) 比と強度眮保

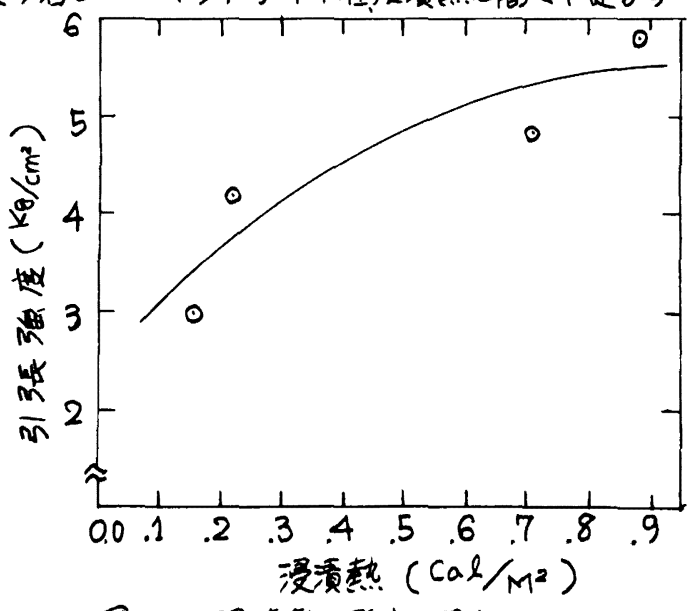

团一2浸清熱と強度の閶係 


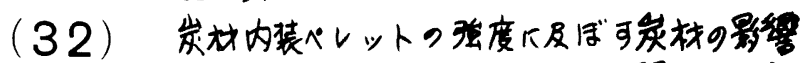

(クロム鉱石のペレタイジングに䦦する研究 I）

昭和電工金属開永空吉村宽一

金属研究所，萡司孝志田好应

\section{1、緒言}

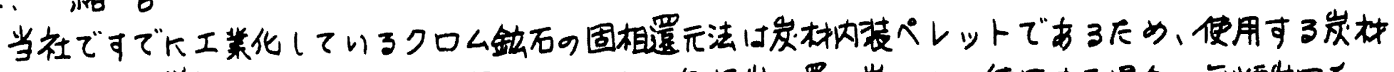

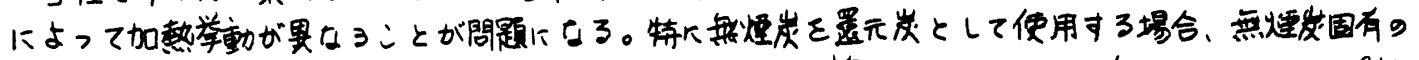

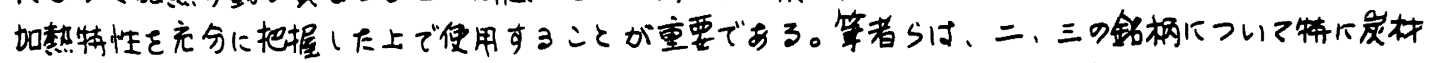

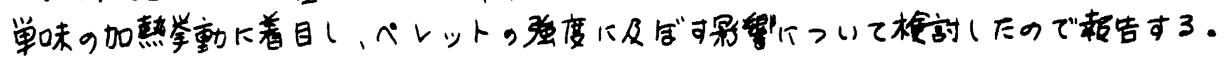

2、实験方法

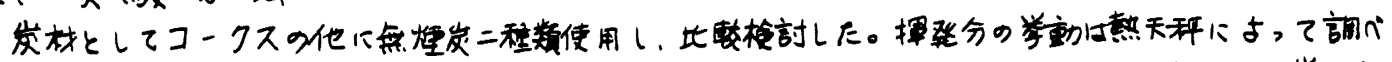

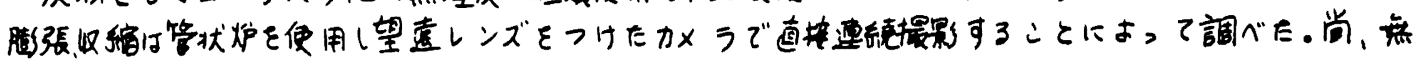

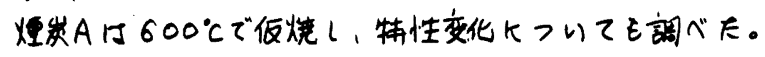

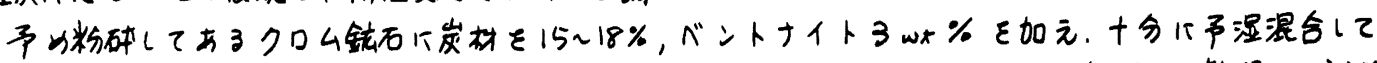

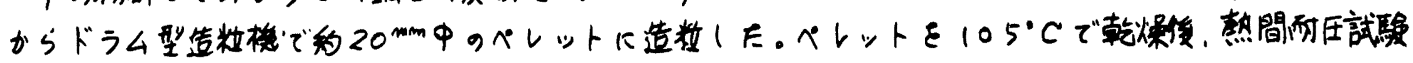
機により所求の温度で强度测定した。

3、結果と考察

表一1に使用炭材の工菜分所值，表一2に熱間におけ3ペレッ

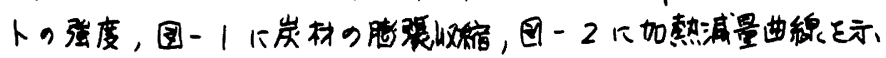

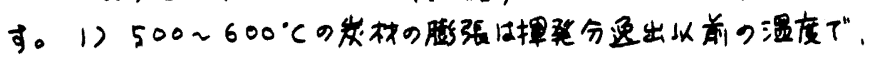

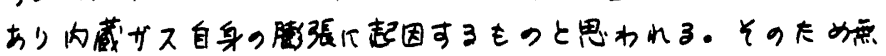

表一工莱分析值（）。

\begin{tabular}{|c|c|c|c|}
\hline & 因定岩素 & 揭䜤分 & 厌 分 \\
\hline ב-クス & 88.0 & 2.1 & 9.9 \\
\hline 点㛐炭A & 75.6 & 11.9 & 12.5 \\
\hline 慜雨岸B & 79.0 & 7.8 & 13.2 \\
\hline
\end{tabular}

焐交欧合ペレットは、コークス配合ペレットより強度が少る。

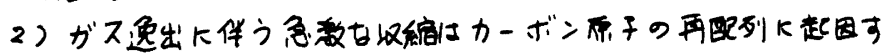

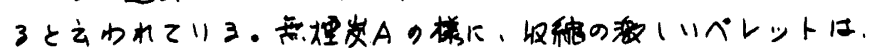

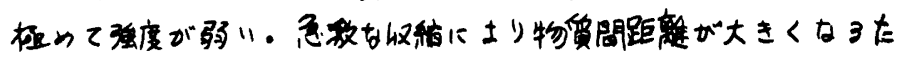

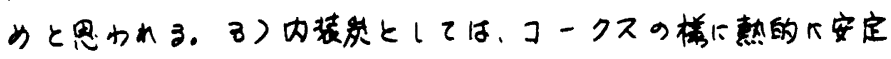

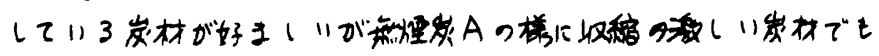

\begin{tabular}{|c|c|c|}
\hline 表 - 2 & \multicolumn{2}{|c|}{ ペレットg㷫間強度 $(\mathrm{kg})$} \\
\hline & $500^{\circ} \mathrm{C}$ & $900^{\circ} \mathrm{C}$ \\
\hline$コ ー ク ス$ & 25 & $80 \mathrm{~kg}$ 以上 \\
\hline 要煙岩A & 18 & 25 \\
\hline 炡宸 B & 18 & 40 \\
\hline
\end{tabular}
低温作烧することにより㱿的安定させることができる。

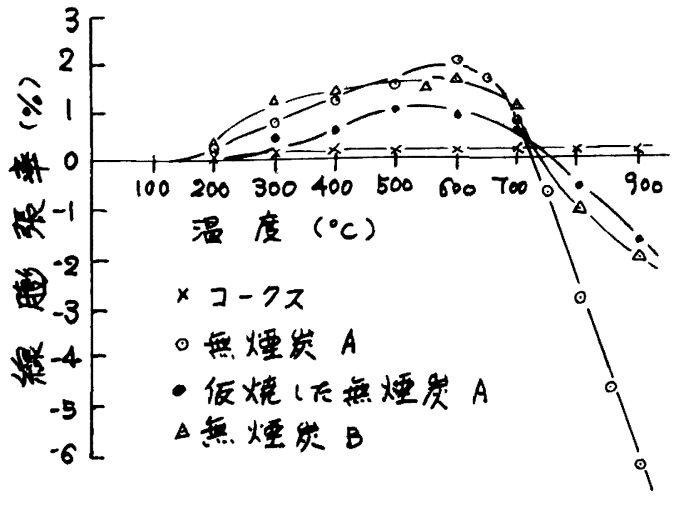

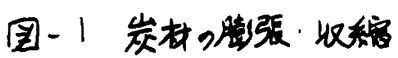

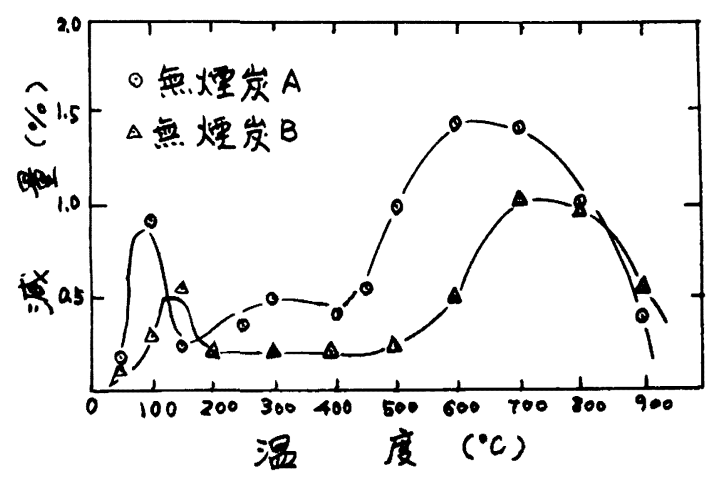

国-2加热減是曲稳 
(33) 炭材湦合ペレットの膨脹性におよばす炭材の種類上粒子径の影㫫

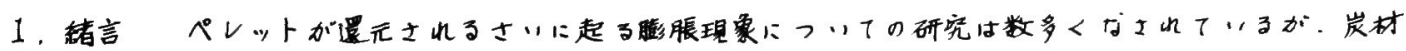

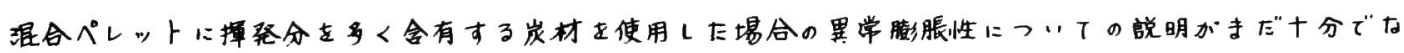

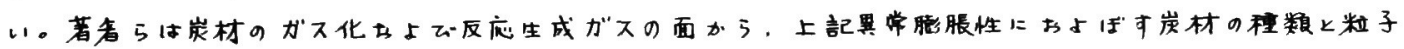
径の影唓について梌討をく山えた。

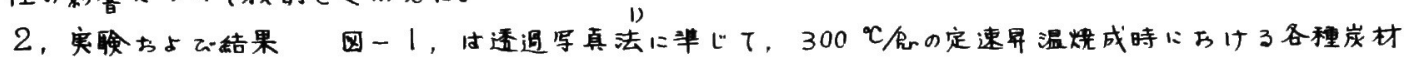

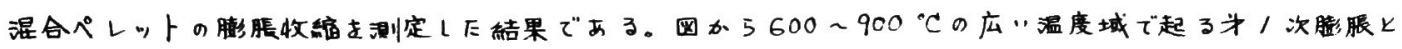

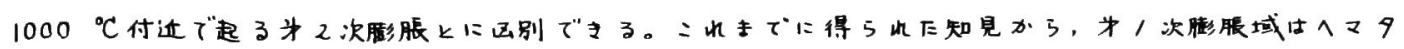

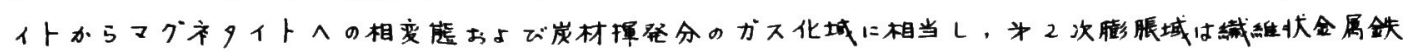

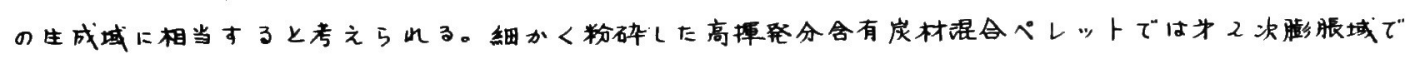

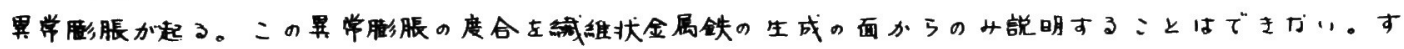

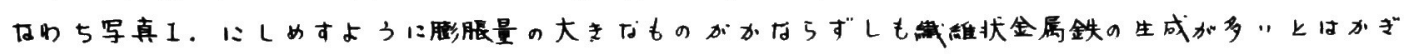

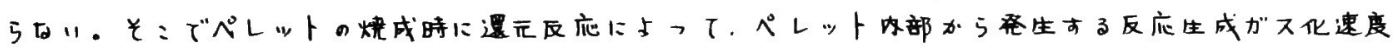

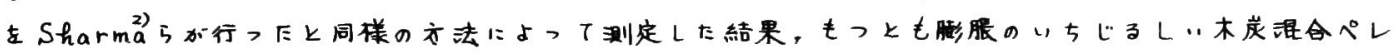

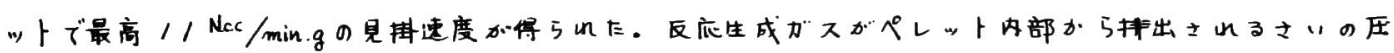
力指失によって得られるペレット内部の压力增加をKozeny-Carmanの式によつて概算するに0.4〜0.5 $\mathrm{Kg} / \mathrm{cm}^{2}$ の竟国にちる。

この程度のペレット内部压力增加がペレット㮖

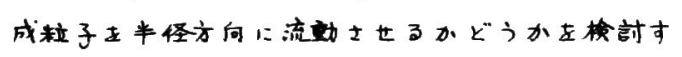

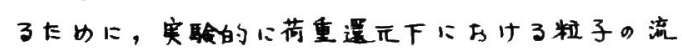

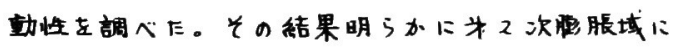
おいてヘレット榑成粒子莌の侍重による影響か認 められる:とから，綎状金属铁の生成とともに ペレット内部がス压力の增加もペレントの微脹杖 穜のーっ上考えられる。

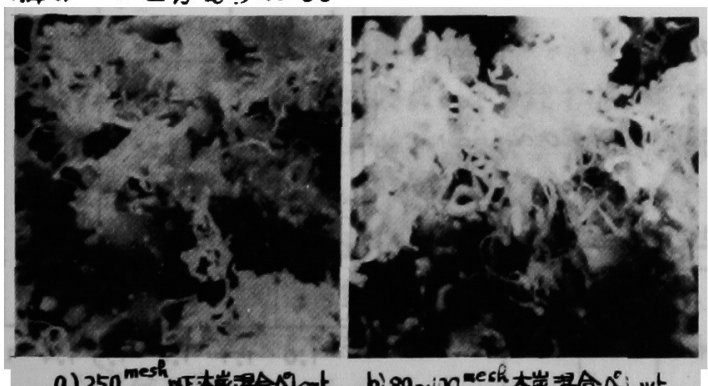

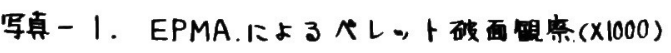
文献 DW. Radmacher: Brennstoff (hem. 30 (1949), P $377, \quad$ 2) S.K. Sharma, R.G.Ward: JISI. $205(1967), p 196$

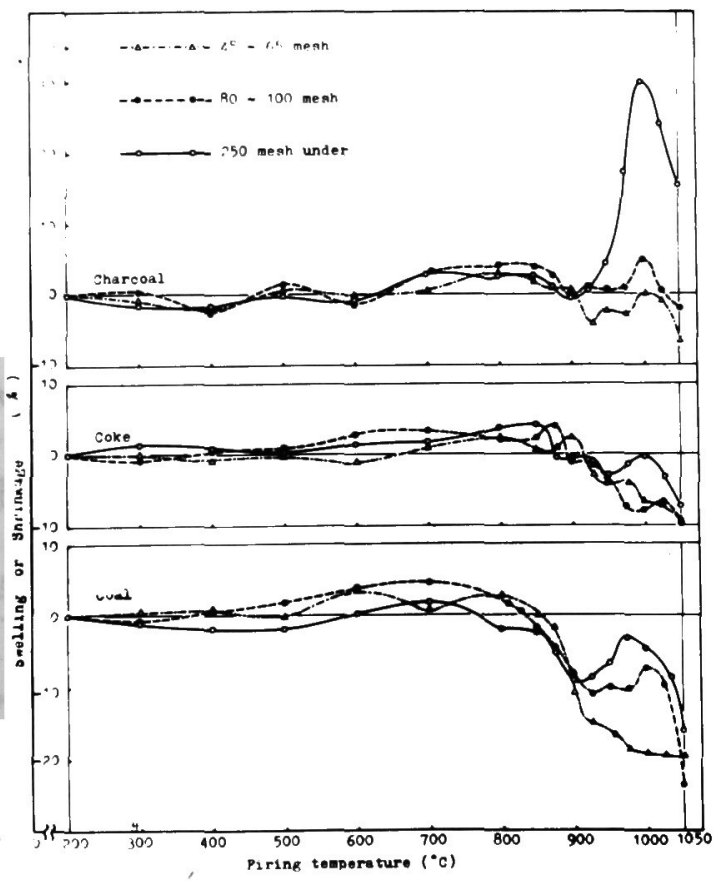

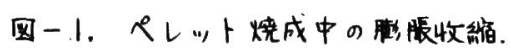


'74- S 374

(34)
628.38: 669.162.252.8: 669.184.263

$669.141 .17: 669.181 .4$

製鉄ダストによる迬元ペレットの装造

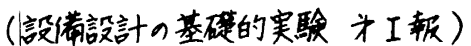

住友金属中央技怵研究所工博湾边正次郎

○山田牶椑

\section{I 粕 言}

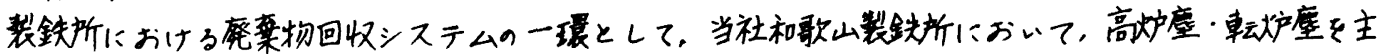

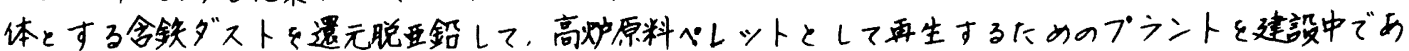

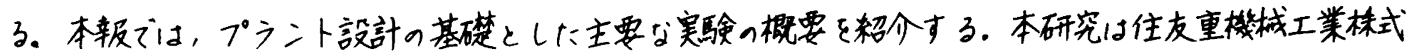
会社と共同で行なわれた。

\section{I 設借概要}

フローシートの詳細は，講演時に報告するが，方に示すようふ程

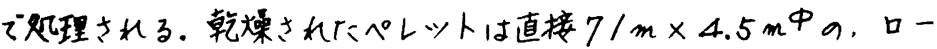
多りーキルンに装入されて、金属ぺレットとされる。輩品にはスング 成分・Sの含有・多いため，高炉原料として使用される。

\section{II 原料前处理}

原料スンリーは，35\%以上の旅 度とする:とによクケーキ水分の变 動防ぎ，フィルタードうム回転数 自動制御以よってドライヤーへの定 量供粭女保証する方式とした。乾燥 水分は $7 \%$ を目標とする。

为造粒.予熟

ウスタイトの酸化発㷫，炭栈の消

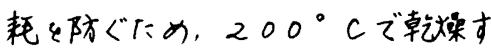
3. 造粒条件的適当人選択する:と
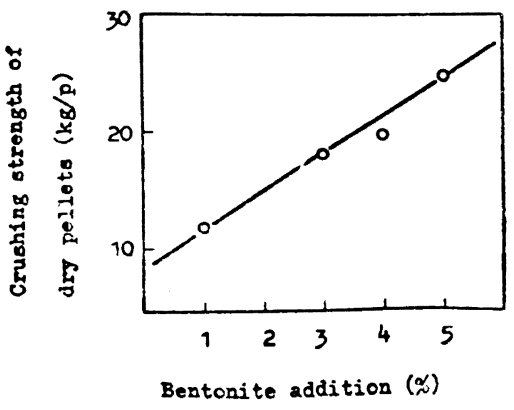

因1乾煤ペレツト生浿强度(常温)

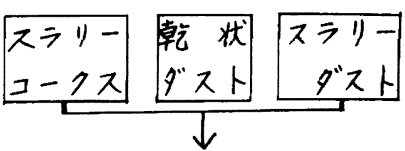

混合ベースン

$\downarrow$ ベルトフィルター

$\downarrow$ ロータリードライヤー $\downarrow$ ボール・ミル $\downarrow$ 四型造粒機<smiles>[AlH2]</smiles>
バンドドライヤー

$\downarrow$

で、因1に示すようら強度のペレツ

トを得る:とができ,ロータリーキルンに直椄装入が可能である。

$\nabla \quad$ 還元

困2に示すようにキルン内でペレツトの弱化が生じる。:の

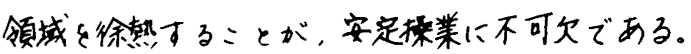

製品は表1下示す小うに良く脱亚鉛され，压潢强度も心00〜

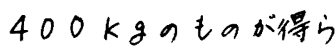
表 1 k下.

VIさぬ

シれらの实駼をもと に案したプラントは 明年4月完工予定で， 現在工事中である。

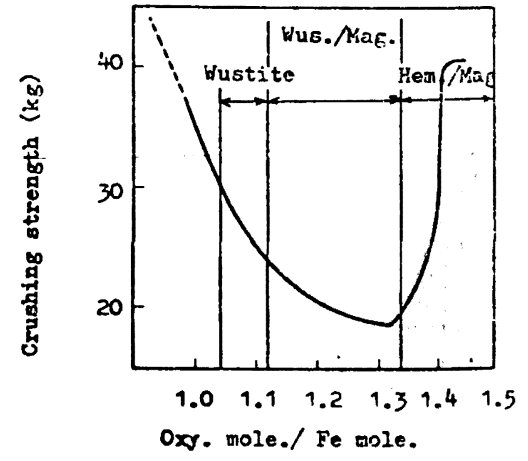

因2 キルン内ペレット強度推栘 